\title{
Identification of microsatellite loci in Pinus tecunumanii
}

\author{
Valderês Aparecida de Sousa ${ }^{1}$, Camila C Mantello², Ananda Virginia de Aguiar ${ }^{1 *}$, Daiane Rigoni Kresting ${ }^{1}$, \\ Anete Pereira de Souza ${ }^{2}$, Laila Toniol Cardin ${ }^{3}$ \\ From IUFRO Tree Biotechnology Conference 2011: From Genomes to Integration and Delivery \\ Arraial d'Ajuda, Bahia, Brazil. 26 June - 2 July 2011
}

\section{Background}

Pinus tecunumanii has displayed good performance in tropical regions of Brazil and showed high potential for commercial exploitation. Embrapa Forestry and its partners own many of the species seed production areas. In spite of its importance, the majority of $\mathrm{P}$. tecunumanii germplasm collections remain still genetically uncharacterized. Thus identifying genetic markers is an important tool to genetically characterize these collections.We describe the initial steps to develop microsatellites for Pinus tecunumanii by enriched library construction with the ultimate goal of characterizing accessions of the germplasm collections of EMBRAPA.

\section{Methods}

The genomic-enriched library was constructed following the protocol described by [1]. The genomic DNA of $P$. tecunumanii was digested with AFAI and enriched in $(\mathrm{CT})_{8}$ and $(\mathrm{GT})_{8}$ repeats. Enriched fragments were amplified by polymerase chain reaction (PCR), connected to a pGEM T-easy vector and transformed into competent XL1- blue Escherichia coli cells. The positive clones were selected using the B-galactosidase gene and then grown overnight in an HM/F medium with ampicillin. After PCR 95 positive clones were sequenced in both directions using the T7 and SP6 primers as well as the Big Dye terminator Kit. The sequences were assembled and edited in Seqman (DNAStar), the repetitive regions were found using the Simple Sequence Repeat Identification Tool [2]. Primer select (DNAStar) and Primers Plus were used to design primer pairs flanking the microsatellite regions.

\footnotetext{
* Correspondence: ananda@cnpf.embrapa.br

'Embrapa Forestry, Brazilian Agricultural Research Corporation, Colombo,

Paraná, 83411-000, Brazil

Full list of author information is available at the end of the article
}

\section{Results and conclusion}

Of the ninety five sequences cloned only eleven contained microsatellite sequences and five showed repeats and adequate flanking regions for primer design. The observed proportion of dinucleotide was 5.26\% (5), while trinucleotide and tetranucleotide proportions were $1.05 \%$ (1) and $5.26 \%$ (5), respectively. Ninety one percent of nucleotides were simply perfect and $9 \%$ were compost perfect. The explanation for this low yield (11.6\%) can be attributed to the genomic-enriched procedure. To overcome this problem this procedure will be repeated. The obtained sequences will be used for validation of $P$. tecunumanii microsatellite primers and used to estimate the genetic diversity from the germplasm collection located in various regions of Brazil.

\section{Acknowledgments \\ The authors would like to thank Selma Buzzetti de Moraes and Mario Luiz Teixeira de Moraes for their assistance with DNA extraction procedures and the Valor Florestal Company for collecting material used in this research.}

\section{Author details}

${ }^{1}$ Embrapa Forestry, Brazilian Agricultural Research Corporation, Colombo, Paraná, 83411-000, Brazil. ²UNICAMP, Campinas, São Paulo, 13083-970, Brazil. ${ }^{3}$ UNESP, Ilha Solteira, São Pauloa, 15385-000, Brazil.

\section{Published: 13 September 2011}

\section{References}

1. Billote N, Risterucci AM, Baurens FC: Microsatellite enriched libraries: applied methodology for the development of SSR markers in tropical crops. Fruits 1999, 54:277-288.

2. Temnykh S, DeClerck G, Lukashova A, Lipovich L, Cartinhour S, McCouch S: Computational and experimental analysis of microsatellites in rice (Oryza sativa L.): frequency, length variation, transposon associations, and genetic marker potential. Genome Research 2011, 11:1441-1452.

doi:10.1186/1753-6561-5-S7-P1

Cite this article as: Aparecida de Sousa et al:: Identification of microsatellite loci in Pinus tecunumanii. BMC Proceedings 2011 5(Suppl 7): P1.
(C) 2011 Aparecida de Sousa et al; licensee BioMed Central Ltd. This is an open access article distributed under the terms of the Creative Commons Attribution License (http://creativecommons.org/licenses/by/2.0), which permits unrestricted use, distribution, and reproduction in any medium, provided the original work is properly cited. 